\title{
Pharmaceutical Strength Unit
}

National Cancer Institute

\section{Source}

National Cancer Institute. Pharmaceutical Strength Unit. NCI Thesaurus. Code C117055.

The unit of measure for the content of an active ing redient, expressed quantitatively per dosage unit. 